Brol M., Czetwertyński S., Grupy interesów w spoteczeństwie sieciowym, „Ekonomia i Prawo”, Polszakiewicz B., Boehlke J. (red.), Tom XII, nr 2/2013, ss. 309-319. DOI: http://dx.doi. org/10.12775/EiP.2013.024

\author{
Marcin Brol*, SŁaWomir CZetWertyńSKI**
}

\title{
GRUPY INTERESÓW W SPOŁECZEŃSTWIE SIECIOWYM
}

\section{STRESZCZENIE}

Niniejszy artykuł jest próbą wykazania wpływu czynników charakterystycznych dla Internetu na funkcjonowanie grup interesu. Postawiono tu tezę głoszącą, że grupy interesów sfery wirtualnej wzmacniają swoje oddziaływanie dzięki efektowi sieci oraz asynchroniczności Internetu. Rozważania poparto przykładami współczesnych grup interesów wiązanych ze sprzeciwem wobec ratyfikacji ACTA oraz przewrotu politycznego określanego mianem „arabskiej wiosny”.

Słowa kluczowe: grupy interesu, społeczeństwo sieciowe, Internet

Klasyfikacja JEL: D7, D8

\section{PRESSURE GROUPS IN NETWORK SOCIETY}

\author{
SUMMARY
}

In this article authors tries to demonstrate specific factors that affect functioning of Internet pressure groups. The main thesis is that the pressure groups of the virtual sphere increase its impact through the network effect and asynchrony of the Internet. To support

* Marcin Brol, Uniwersytet Ekonomiczny we Wrocławiu, Wydział Nauk Ekonomicznych, Katedra Makroekonomii, tel. +48 793453 767, e-mail: marcin.brol@ue.wroc.pl (Autor wskazany do korespondencji).

** Sławomir Czetwertyński, Uniwersytet Ekonomiczny we Wrocławiu, Wydział Ekonomii, Zarządzania i Turystyki w Jeleniej Górze, Katedra Mikroekonomii, tel. +48 501666 082, e-mail: slawomir.czetwertynski@ue.wroc.pl. 
a theory with facts, authors presented some pressure groups that has been active during anti-ACTA protests and political turmoil in north Africa, known as "Arab Spring".

Keywords: pressure groups, network society, Internet

JEL Classification: D7, D8

\section{WSTĘP}

Współczesne interakcje społeczne coraz częściej zachodzą w sferze wirtualnej - cyfrowej przestrzeni sieci Internetu. Dotyczy to zarówno kontaktów o charakterze osobistym, biznesowym, jak i ogólnospołecznym. Zjawisko to spotęgowało pojawienie się portali społecznościowych, takich jak Facebook, Twitter czy My Space. Serwisy te początkowo wspierać i umacniać miały więzi społeczne, które zawierane są w świecie realnym. Szybko okazało się jednak, że to dzięki nim więzi takie są tworzone niezależnie od świata rzeczywistego. W wymiarze społecznym oznacza to powstawanie sieciowych wspólnot. W sferze ekonomicznej natomiast skutkiem ich funkcjonowania jest pojawienie się grup interesów, które wykorzystują Internet jako forum publiczne. Naciski z ich strony prowadzą do kształtowania postaw konsumenckich, preferencji rynkowych, regulacji publicznych, a nawet ustroju politycznego. Przykładem tego typu działań mogą być zorganizowane protesty w sprawie ACTA (Anti-Counterfeiting Trade Agreement) - wielostronnego porozumienia, mającego ustalić międzynarodowe standardy $\mathrm{w}$ walce $\mathrm{z}$ naruszeniami własności intelektualnej. A także tzw. arabska wiosna - wydarzenia, które doprowadziły do upadku kilku rządów w krajach Afryki Północnej.

Celem niniejszego artykułu jest uporządkowanie stanu wiedzy dotyczącej funkcjonowania grup nacisków w społeczeństwie sieciowym. Autorzy stawiają tezę dotyczącą funkcjonowania podmiotów uczestniczących w tego typu grupach, tworzonych za pośrednictwem portali społecznościowych, pod wpływem charakterystycznych dla Internetu czynników. Zamyka się ona w stwierdzeniu, że grupy interesów działające w sferze wirtualnej wykorzystują efekt sieci oraz asynchroniczność interakcji w celu zwiększania swojej siły oddziaływania. Internet umożliwia funkcjonowanie nowej sfery publicznej, w której podmioty rynkowe uwolnione zostały od ograniczeń materialnych, przestrzennych oraz czasowych.

\section{GRUPY INTERESÓW W WARUNKACH SIECIOWYCH}

Rozważania dotyczące funkcjonowania grup społecznych, dążących do osiągnięcia wspólnych korzyści w ramach współczesnego społeczeństwa siecio- 
wego, rozpocząć należy od zdefiniowania pojęcia grupy interesów. Pojęcie to utożsamiane bywa niesłusznie $\mathrm{z}$ korupcją, między innymi ze względu na fakt, że istotą procesu zwanego lobbingiem (w który zaangażowane są grupy interesów) jest uzyskanie korzyści przez wąską grupę społeczną. Stąd też, zjawisko to jest ściśle regulowane. Zgodnie z Ustawa o dziatalności lobbingowej w procesie stanowienia prawa ${ }^{1}$ przez lobbing rozumieć należy każde działanie prowadzone metodami prawnie dozwolonymi zmierzające do wywarcia wpływu na organy władzy w procesie stanowienia prawa. Działalność taką prowadzi się zazwyczaj na rzecz osób trzecich, zazwyczaj utożsamianych z grupami interesu, zwanych też grupami nacisku. Te z kolei można zdefiniować jako grupę jednostek połączoną więzami wspólnych interesów i korzyści, której członkowie mają świadomość istnienia tych więzów. Jednocześnie grupy te wyrażają zainteresowanie określonym abstrakcyjnym, czy też materialnym celem oraz dążą do jego osiągniecia poprzez świadomy wpływ na politykę publiczną 2 .

W warunkach usieciowienia społeczeństwa, grupy interesów, jak zresztą wszelkie inne, podlegają tzw. efektom sieci. We współczesnej ekonomii zjawisko to określa się mianem efektów zewnętrznych sieci, które wywołują sprzężenie zwrotne ${ }^{3}$. Za sprawą G. Gilder efekt sieci nazywany jest również Prawem Metcalfe'a, od nazwiska inżyniera firmy Intel, który jest autorem wykresu przedstawiającego relację między wartością sieci a liczbą urządzeń ją tworzących (rysunek 1.).

W praktyce zależność przedstawiona przez R.M. Metcalfe'a wskazuje liczbę połączeń w zależności od liczby węzłów, wyrażoną wzorem $\frac{n(n-1)}{2}$ (gdzie $n$ to liczba węzłów sieci). Zależności zatem opisanych Prawem Metclfe'a nie można bezpośrednio odnieść do sieci tworzonych przez ludzi, gdyż musieliby być oni podmiotami homogenicznymi, a interakcje zachodzące między nimi musiałby mieć jednakową wartość. Nie zmienia to jednak faktu, że w stosunku do sieci społecznych - w których „urządzeniami” są użytkownicy - można zaobserwować pewne podobieństwa do sieci infrastruktury komunikacyjnej.

1 Ustawa z dnia 7 lipca 2005 r. o dziatalności lobbingowej w procesie stanowienia prawa, Dz. U. z 2005 r. Nr 169, poz. 1414 z późn. zm., art. 2.

${ }^{2}$ L. Graniszewski, C. Piątkowski, Grupy interesu w Unii Europejskiej, Wydawnictwo sejmowe, Warszawa 2004, s. 9-11.

${ }^{3}$ C. Shapiro, H.R. Varian, Potega informacji. Strategiczny przerwodnik po gospodarce cyfrowej, Wydawnictwo HELION, Gliwice 2007 s. 191-195, 199-200.

${ }^{4}$ G. Gilder, Telecosm: Metcalfe's Law and legacy, „Forbes ASAP”, March 29, 1993, s. 158-167. 


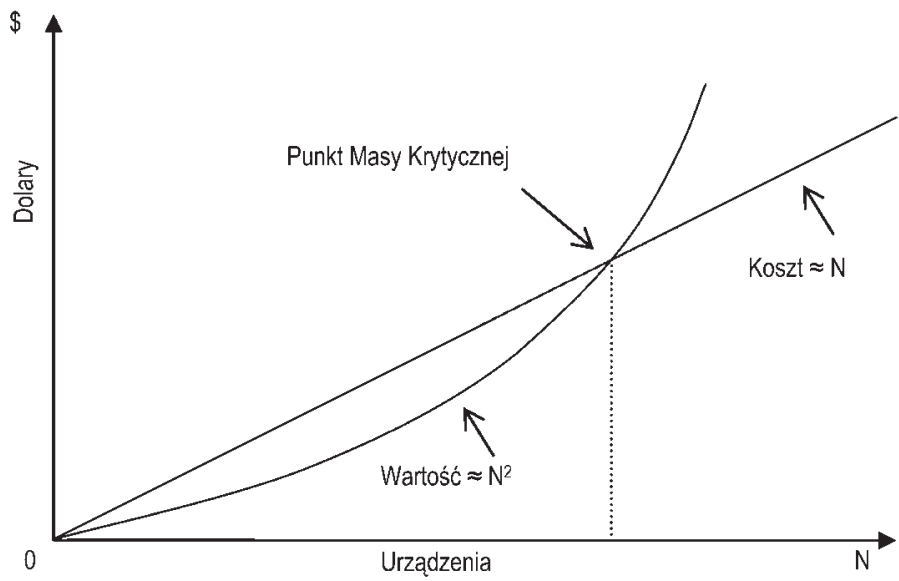

Rysunek 1. Relacja wartości sieci oraz kosztów jej tworzenia względem jej rozmiaru wg R.M. Metcalfe’a Źródło: B. Metcalfe ${ }^{5}$, Metcalfe's Law Recurses Down the Long Tail of Social Networking, 2006, http://vcmike.wordpress. com/2006/08/18/metcalfe-social-networks/ (20.01.2013).

Po pierwsze, w sieciach społecznych występują efekty zewnętrzne sieci, które w swej naturze są pozytywne. Zgodnie z podręcznikową definicją w przypadku ich występowania „[...] użyteczność danej osoby z konsumpcji pewnego dobra zależy od liczby innych osób konsumujących to dobro”6. Wyrażając to inaczej, liczba podmiotów (osób) tworzących sieć wpływa na jej użyteczność dla poszczególnych jej uczestników.

Po drugie, istnieje pewien punkt masy krytycznej (rysunek 1.), po przekroczeniu którego koszty uczestnictwa w sieci są mniejsze niż korzyści płynące z uczestnictwa w niej. Po przekroczeniu tego punktu wzrost użyteczności jest więcej niż proporcjonalny względem wzrostu kosztu uczestnictwa. Wyrazem tego jest sprzężenie zwrotne, za sprawą którego silni stają się silniejsi, a słabi słabsi ${ }^{7}$. Sieci, które osiągnęły swój punkt krytyczny przyciągają coraz szerszą liczbę uczestników, powodując de facto ich odpływ z sieci konkurencyjnych.

Chociaż więc sieci społeczne nie są sieciami infrastrukturalnymi, a ich analiza nie przebiega tak liniowo jak chociażby w przypadku sieci telefonicznych, to jednak specyfika struktury sieciowej wyraża się w nagłej ekspansji.

${ }^{5}$ Właściewie Robert Melancton Metcalfe. Jednak R.M. Metcalfe posługuje się przydomkiem „Bob”, stąd B. Matcalfe.

${ }^{6}$ H.R. Varian, Mikroekonomia. Kurs średni-ujęcie nowoczesne, Wydawnictwo Naukowe PWN, Warszawa 2005, s. 630.

7 C. Shapiro, H.R. Varian, Potega ..., op. cit., s. 191-195. 
Oczywiście o ile nastąpi przekroczenie punktu masy krytycznej, który można określić w zasadzie post factum.

Efekt sieci miał wpływ zarówno na formownie się standardu poczty e-mail, jak i dominacji Facebooka wśród mediów społecznościowych. Wpłynął również na przebieg organizacji protestów przeciw wprowadzeniu ACTA. Uczestnicy manifestacji posłużyli się w tym celu aplikacjami internetowymi, przede wszystkim związanymi z mediami społecznymi. Organizacja oraz koordynacja protestów odbywała się poprzez portale społecznościowe, w głównej mierze Facebooka i Twittera. Co ciekawe śledząc hasła i profile dedykowane tylko protestom, np. „Stop ACTA” czy „Nie dla ACTA”, które pojawiały się w tych serwisach, zauważyć można, że nie każda propozycja zorganizowania demonstracji została zaakceptowana.

W koncepcji funkcjonowania sfery publicznej wg J. Habersmasa kluczowymi postaciami są aktorzy publiczni ${ }^{8}$. W wirtualnej sferze publicznej oprócz aktorów występują także statyści, czyli osoby obserwujące wydarzenia, lecz w ich bezpośrednio nieuczestniczący, które Habermas nazywał ogólnie „rozproszoną publicznością" ". Statyści są obserwatorami dialogów przebiegających w sferze publicznej. Aktorzy z kolei aktywnie uczestniczą w dialogach. W przypadku sprzeciwu wobec ratyfikacji ACTA statyści obserwujący profile na portalach społecznościowych przemienili się w aktorów. Co więcej, eskalacja ich aktywności znalazła swój wyraz w sferze realnej, tak więc wyszła poza sferę wirtualną. Zasadniczym problemem jest określenie jakie wydarzenie spowodowało przemianę statystów w aktorów. Prześledzenie wydarzeń dzień po dniu pozwala postawić tezę, że nie był to pojedynczy impuls, lecz fala zaangażowania, która rosła z każdą chwilą, co z kolei powodowało kumulację niezadowolenia.

To swoiste zjawisko śnieżnej kuli jest właśnie wyrazem efektu sieci. W omawianym kontekście oznacza to, że im więcej osób zdeklarowało swój udział, tym większa była korzyść jaką odnieśli wszyscy manifestanci. Zadziało więc dodatnie sprzężenie zwrotnie, potęgujące liczbę protestujących. Tymczasem tam, gdzie odzew był już na początku niewielki, nie udało się zazwyczaj zgromadzić większej liczby uczestników - na skutek ujemnego sprzężenia zwrotnego. W pierwszym przypadku zatem osiągnięto punkt masy krytycznej, natomiast $\mathrm{w}$ drugim, nie.

W wyniku tego typu działań nie wyłoniono też lidera, który nadawałby ton protestom. Niektórzy ich inicjatorzy w jednym dniu zyskiwali poklask, a już w następnym nie byli w stanie zgromadzić większych rzesz zaintereso-

8 J. Habermas, Strukturalne przeobrażenia sfery publicznej, PWN, Warszawa 2007, s. 100-122.

9 Ibidem, s. 112. 
wanych. Co należy łączyć właśnie z wywołaniem dodatniego lub ujemnego sprzężenia zwrotnego. Innym ciekawym zjawiskiem było stosunkowo szybkie wygaśnięcie protestów, po uzyskaniu zapewnień ze strony większości rządów (w tym także polskiego) o czasowym odstąpieniu od ratyfikacji umowy. Tę sytuację również należy tłumaczyć efektami sieci, gdyż zaprzestanie protestów przez najmniej zaangażowanych spotęgowała spadek użyteczności manifestacji dla wszystkich uczestników poniżej punktu masy krytycznej.

Brak wyłonienia się konkretnego lidera $w$ ramach całej akcji sprzeciwu społecznego wobec ACTA dowodzi również, że grupa nacisku stworzona w tym konkretnym przypadku ma charakter sieci partnerskiej, czyli takiej, w której wszyscy uczestnicy są równi, niezależnie o statusu społecznego, ograniczeń przestrzennych lub czasowych. Czynnikiem spajającym sieć stał się wspólny cel - sprzeciw. Na jego bazie uformowała się sieć. Nie oznacza to jednak, że każda grupa nacisku nie ma personalnie ukształtowanego lidera, który narzuca cel. Powstawanie grup bez lidera uznać można za ilustrację zjawiska, które scharakteryzował J. Ortega y Gasset. Bunt mas, opisany przez niego, dotyczył ludzi młodych charakteryzujących się większym przywiązaniem do praw niż obowiązków ${ }^{10}$. Wskazywał on jednocześnie korzyści płynące z buntu - rozrost życia społecznego, jak i zagrożenia w postaci demoralizacji ludzkości ${ }^{11}$. Brak lidera wynikać może zatem z egoizmu i braku „moralności” (do tego pojęcia odwoływał się zarówno J. Habermas, jak i J. Ortega y Gasset). Wskazywałby na to również przebieg protestów i ich gwałtowne wygaśnięcie po spełnieniu egoistycznych żądań aktorów, którzy na powrót stali się statystami.

\section{ASYNCHRONICZNOŚĆ INTERAKCJI}

Czasoprzestrzeń Internetu charakteryzuje się asynchronicznością interakcji. Pod tym hasłem rozumie się zarówno przełamanie ograniczeń przestrzennych jak i synchronizacji czasowej uczestników relacji12. Należy jednak do tych dwóch cech zaliczyć również asynchroniczność statusu społecznego. Oznacza to, że dialog może swobodnie przebiegać między osobami z uboższych warstw społecznych o niższych kompetencjach technicznych a osobami z najwyżej klasy. Oczywiście, o ile nie bierze się pod uwagę osób wykluczonych cyfrowo.

${ }^{10}$ J. Ortega y Gasset, Bunt mas, Wydawnictwo Literackie MUZA SA, Warszawa 2004, s. $208-211$.

11 Ibidem, s. 137.

12 P. Levinson, Miękkie ostrze, czyli historia i przyszłośc rewolucji informacyjnej, Warszawskie Wydawnictwo Literackie MUSA SA, Warszawa 2006, s. 224. 
Poszczególne cechy asynchroniczne Internetu wymagają uszczegółowienia. Asynchroniczność miejsca oznacza de facto, że geografia jest martwa. Jak zauważa K. Kelly, w kontaktach w Internecie, fizyczne miejsce nie ma zasadniczego znaczenia ${ }^{13}$. Interakcje mogą się odbywać zarówno między osobami zamieszkującymi tę samą ulicę co różne kontynenty.

Levinson, prócz uniezależnienia działań od rzeczywistego miejsca, podkreśla istnienie asynchroniczności czasu $\mathrm{w}$ interakcjach między podmiotami stosunków społecznych odbywających się poprzez Internet. W takim kontekście Internet stanowi magazyn idei, poglądów i komentarzy, z którego można $\mathrm{w}$ dowolnym momencie skorzystać. W tej kwestii różni się w swej istocie od innych mediów, takich jak radio, telewizja czy też telefon. W przypadku radia i telewizji przekaz nadawany jest zgodnie $z$ harmonogramem. W przypadku rozmów telefonicznych nadawca i odbiorca muszą brać w niej udział jednocześnie, co wymaga synchronizacji.

Asynchroniczność statusu społecznego związana jest bezpośrednio z kosztami krańcowymi komunikacji internetowej. Aktywność w sieciach społecznych funkcjonujących $w$ sferze wirtualnej, polega na wymianie informacji, a więc ostatecznie chodzi o jej replikację. Związane jest to z kosztami publikacji informacji oraz kosztami jej pozyskania. Wielkości te wynikają z czynników wewnętrznych, związanych $\mathrm{z}$ samą naturą informacji w postaci cyfrowej oraz zewnętrznych, zależnych od właścicieli aplikacji internetowych, które tworzą bazę dla tworzenia się mediów społecznych. Czynniki wewnętrzne, czyli natura informacji oraz cyfryzacja, sprawiają, że koszty krańcowe dóbr informacyjnych w Internecie są bliskie zeru ${ }^{14}$. Czynniki zewnętrzne nie wpływają w sposób istotny na tę wartość, gdyż w zasadzie większość aplikacji mediów społecznych jest dostarczana nieodpłatnie ${ }^{15}$. Barierą nie jest więc brak posiadanych środków finansowych. Zjawisko to jest odwrotnością tradycyjnych mediów, szczególnie mass mediów, w których o ile odbiór informacji nie był barierą, o tyle samo

${ }^{13} \mathrm{~K}$. Kelly, Nowe reguty nowej gospodarki. Dziesięć przetomowych strategii dla świata potaczonego siecia, Wig-Press, Warszawa 2001, s. 85-98.

14 Por. O. Shy, The Economics of Network Industries, Cambridge University Press, Cambridge 2001, s. 53; C. Shapiro, H.R. Varian, Potega..., op. cit., s. 15, 36; S. Czetwertyński, Wspólnota jako podstawa produkcji partnerskiej, [w:] A. Szewczyk (red.), Spoteczeństwo informacyjne w świecie rzeczywistym i wirtualnym, Wydawnictwo Naukowe Uniwersytetu Szczecińskiego, Szczecin 2011, s. 9-20.

${ }^{15}$ Brak bezpośrednich opłat za użytkowanie aplikacji mediów społecznych nie oznacza, że są one „darmowe”. Opłatą zwykle przyjmuje postać niepieniężną: uwaga użytkowników poświęcona reklamom; lub związana jest z popytem pochodnym. Por. S. Czetwertyński, The influence of non-transactional products on the income structure of enterprises in the Web economy, [w:] C.F. Hales (red.), Spoteczenstwo informacyjne. Stan i kierunki rozwoju w świetle uwarunkowań regionalnych, Wydawnictwo Uniwersytetu Rzeszowskiego, Rzeszów 2008, s. 351-361. 
nadawanie przekraczało możliwości większości społeczeństwa. W przypadku Internetu, a więc sfery wirtualnej, każdy może tworzyć informacje i je publikować - co jest podstawą aktywności aktorów sfery publicznej.

Te trzy cechy odróżniają Internet od innych mediów dialogu publicznego, które albo wykluczały aktorów nieobecnych przestrzennie, albo wymagały synchronizacji przekazu lub ograniczały statystów poprzez bariery wejścia w poczet aktywnych aktorów. Kształtowały się one wraz z rozwojem technologii teleinformacyjnych. Już media ,analogowe” były wykorzystywane w tworzeniu się grup nacisku. P. Levinson wskazuje, że radio było istotnym elementem nacisku takich przywódców jak W. Churchill, F.D. Roosevelt, A. Hitler czy też J. Stalin ${ }^{16}$. Jednak nie we wszystkich przypadkach można ich działania zakwalifikować do praktyk grup interesu - głównie ze względu na fakt, że stanowili oni władzę legalną. Audycje radiowe wymagały jednak silnych wpływów wynikających z posiadanej już władzy.

W latach 80. i 90. nagrania wideo były wykorzystywane przez fundamentalistów w celu rekrutowania nowych członków. Metoda ta była mniej kosztowna niż korzystanie z mass mediów i pozwoliła na ekspansję grupom o mniejszych możliwościach lub działających w ukryciu. Obecnie wszelkie te praktyki przeniosły się na płaszczyznę Internetu ${ }^{17}$. Dotyczą one zarówno ruchów wolnościowych, jak i terrorystycznych.

Przykładem tego mogą być niedawne wydarzenia, które miały miejsce w krajach północnej Afryki i Bliskiego Wschodu. Fala zamieszek, zwana arabską wiosną rozpoczęła się tam w grudniu 2010 roku i nasiliła się w pierwszej połowie $2011 \mathrm{roku}^{18}$. W Egipcie, Libii, Tunezji i Jemenie doprowadziły one do obalenia rządów, w pozostałych krajach spowodowały zmiany ustrojowe, a w Syrii przerodziły się w trwającą od 2012 roku wojnę domową. Bardzo interesującym zjawiskiem były okoliczności, w których doszło do buntu. Przewrót w Tunezji nazywany jest niekiedy „rewolucją Wikileaks” od nazwy portalu internetowego publikującego "przecieki” z oficjalnej korespondencji dyplomatycznej, obnażające korupcję i wystawny styl życia prominentów reżi$\mathrm{mu}^{19}$. Na portalach takich jak Facebook i Twitter ludzie zaczęli wymieniać się doświadczeniami i obserwacjami dotyczącymi systemu politycznego i gospodarczego, w którym funkcjonują. Tradycyjne media - prasa, radio i telewizja,

${ }^{16}$ P. Levinson, Miękkie..., op. cit., s. 154-161.

${ }_{17}$ M. Adamczuk, Rodzimy terroryzm jako zjawisko zagrażająe bezpieczeństwu w Europie, „Bezpieczeństwo narodowe”, I-2011/17, s. 17.

${ }_{18}$ M. Brol, Wptyw korupcji na gospodarkę krajów Afryki pótnocnej, [w:] T. Bernat (red.), Teoria i praktyka gospodarowania, Uniwersytet Szczeciński, Szczecin 2011, s. 62.

19 R. Stefanicki, Last minute prezydenta Ben Alego, „Gazeta Wyborcza”, 24.01.2011. 
kontrolowane i cenzurowane przez państwo nie zapewniały takich informacji. Dodatkowo Internet stworzył możliwość porozumienia się osób niechętnych reżimowi. Dlatego jedną z pierwszych decyzji rządu Egiptu po wybuchu zamieszek było odcięcie całego kraju od $\operatorname{sieci}^{20}$. W ten sposób próbowano wywołać konieczność synchroniczności interakcji, a tym samym zapobiec przewadze grup nacisku, jaka daje medium Internetu. „Arabska wiosna” dzięki asynchroniczności objęła swym zasięgiem wszystkie klasy społeczne pozwalając im na wymienianie dowolnych informacji.

W przeciwieństwie do protestów w sprawie ACTA, „arabska wiosna“ wykształciła liderów, którzy byli też aktywnymi uczestnikami zajść zarówno w sferze wirtualnej, jak i realnej. Byli to blogerzy, tacy jak Lina Ben Mhenni w Tunezji czy Wael Nawara w Egipcie, dokumentujący protesty i piszący odezwy do ich uczestników ${ }^{21}$.

\section{ZAKOŃCZENIE}

Istnienie grup interesów wpisane jest w ludzką naturę. Tworzymy w ten sposób więzi i staramy się maksymalizować korzyści ekonomiczne, społeczne lub też polityczne. Nie dziwi zatem proces tworzenia się takich grup w Internecie. Asynchroniczność interakcji oraz względna anonimowość w połączeniu $\mathrm{z}$ efektami zewnętrznymi sieci, doprowadziły do rozkwitu powiązań społecznych pomiędzy osobami, które w tradycyjnej sferze publicznej nie byłyby w stanie ich wytworzyć. Ułatwiły to media społeczne, a głównie portale społecznościowe, będące platformami wymiany informacji i skupiające osoby o podobnych przekonaniach. Dodatkowo przestrzeń wirtualna wymyka się kontroli cenzorskiej i regulacjom. Wszystko to spowodowało, że Internet i działający $\mathrm{w}$ jego ramach aktorzy stali się katalizatorem zmian społecznych obserwowanych w ostatnich dwóch dekadach. Najnowszym przejawem tych procesów były naciski w sprawie ACTA oraz „arabska wiosna”. Umasowienie protestów możliwe było dzięki postępowi technicznemu, który uniezależnił publiczność od miejsca, czasu i statusu społecznego.

Zmierzch dawnego ładu społecznego i formowanie się społeczeństwa sieciowego znajduje wydźwięk w kształcie grup interesów ery Internetu. Sieci społeczne sfery wirtualnej tworzące się wokół wspólnych celów można podzielić na trzy typy. W pierwszym, cel wypływa z samej grupy społecznej. Sieć konstruuje się dosłownie dzięki więzi jaką odczuwają jej członkowie. Przy tym

\footnotetext{
${ }^{20}$ Ibidem.

${ }^{21}$ K. Andersen, The Protester, „Time Magazine”, Vol. 178, No. 25/2011, s. 3-9.
} 
więź ta jest oparta na egoistycznych przesłankach. Efekt sieci oraz sprzężenie zwrotne powalają na rozkwit tego typu grup interesów w bardzo szybkim tempie. Podobnie bardzo szybko następuje ich rozkład, gdy tylko cel zostanie osiągnięty (lub staje się jasnym, że osiągniętym być nie może).

Do drugiego typu należy zaliczyć grupy interesu, w których cel jest narzucony przez konkretny podmiot (lidera). Sieci konstruowane są wokół postulatów mniejszości i narzucone większości. Tego typu sieci często mają charakter fundamentalistyczny, a realizacja celu skłania do ustalania nowych przez podmioty nimi sterujące. W sieciach tych wykorzystuje się efekty zewnętrzne sieci oraz dodatnie sprzężenie zwrotne, jednak jej inicjatorzy starają się nie dopuścić do spadku masy krytycznej i w efekcie jej rozpadu.

Ostatni typ jest formą pośrednią, co znaczy, że sieć tworzy się samoistnie, lecz w jej trakcie kreują się osoby pełniący rolę liderów (bądź lidera). W tym przypadku sieć może ulec rozproszeniu lub przekształceniu. Liderzy mogą usiłować zmienić sieć, tak by stała się tożsama $z$ ich celami. Mogą także ograniczyć się do podtrzymywania faktu ich zaistnienia. Należy jednak domniemywać, że w tym przypadku sieć znajduje się poniżej poziomu masy krytycznej.

Grupy interesów w społeczeństwie sieciowym są wypadkową strukturalnych katalizatorów (efekt sieci i sprzężenie zwrotne) i nowoczesnej komunikacji (asynchroniczność Internetu). Aczkolwiek nie mogłyby funkcjonować bez chęci realizacji wspólnych celów. Współczesne społeczeństwo tym różni się od wcześniejszych, że ma do dyspozycji potężne narzędzie, które pozwala na skupianie siły nacisku ponadprzestrzennej, ponadczasowej oraz ponadklasowej.

\section{BIBLIOGRAFIA}

Adamczuk M., Rodzimy terroryzm jako zjawisko zagrażające bezpieczeństwu w Europie, „Bezpieczeństwo narodowe”, I-2011/17.

Andersen K., The Protester, „Time Magazine”, Vol. 178, No. 25/2011.

Brol M., Wptyw korupcji na gospodarkę krajów Afryki pótnocnej, [w:] T. Bernat (red.), Teoria i praktyka gospodarowania, Uniwersytet Szczeciński, Szczecin 2011.

Czetwertyński S., The influence of non-transactional products on the income structure of enterprises in the Web economy, [w:] C.F. Hales (red.), Spoteczenstwo informacyjne. Stan i kierunki rozwoju w świetle uwarunkowań regionalnych, Wydawnictwo Uniwersytetu Rzeszowskiego, Rzeszów 2008.

Czetwertyński S., Wspólnota jako podstawa produkcji partnerskiej, [w:] A. Szewczyk (red.), Spoteczeństwo informacyjne w świecie rzeczywistym i wirtualnym, Wydawnictwo Naukowe Uniwersytetu Szczecińskiego, Szczecin 2011.

Gilder G., Telecosm: Metcalfe's Law and legacy, „Forbes ASAP”, March 29, 1993. 
Graniszewski L., Piątkowski C., Grupy interesu w Unii Europejskiej, Wydawnictwo sejmowe, Warszawa, 2004.

Habermas J., Strukturalne przeobrażenia sfery publicznej, PWN, Warszawa 2007.

Kelly K., Nowe reguty nowej gospodarki. Dziesięć przetomowych strategii dla świata potaczonego sieciq, WIG-Press, Warszawa 2001.

Metcalfe B., Metcalfe's Law Recurses Down the Long Tail of Social Networking, 2006, http://vcmike.wordpress.com/2006/08/18/metcalfe-social-networks/ (20.01.2013).

Ortega y Gasset J., Bunt mas, Wydawnictwo Literackie MUZA SA, Warszawa 2004.

Shapiro C., Varian H.R., Potega informacji. Strategiczny przewodnik po gospodarce cyfrowej, Wydawnictwo HELION, Gliwice 2007.

Shy O., The Economics of Network Industries, Cambridge University Press, Cambridge 2001.

Stefanicki R., Last minute prezydenta Ben Alego, „Gazeta Wyborcza”, 24.01.2011.

Ustawa z dnia 7 lipca 2005 r. o dziatalności lobbingowej w procesie stanowienia prawa, Dz. U. z 2005 r., Nr 169, poz. 1414 z późn. zm., art. 2.

Varian H.R., Mikroekonomia. Kurs średni - ujęcie nowoczesne, Wydawnictwo Naukowe PWN, Warszawa 2005. 
